\title{
Who are the women and men in Veterans Health Administration's current spinal cord injury population?
}

\author{
Catherine M. Curtin, MD; ${ }^{1-2 *}$ Paola A. Suarez, MPH; ${ }^{3}$ Lisa A. Di Ponio, MD; ${ }^{4}$ Susan M. Frayne, MD, MPH ${ }^{3,5}$ \\ ${ }^{1}$ Rehabilitation Research and Development, Department of Veterans Affairs (VA) Palo Alto Health Care System, Palo \\ Alto, CA; ${ }^{2}$ Division of Plastic Surgery, Stanford University, Stanford, CA; ${ }^{3}$ Center for Health Care Evaluation, VA Palo \\ Alto Health Care System, Menlo Park, CA; ${ }^{4}$ Department of Physical Medicine and Rehabilitation, VA Ann Arbor \\ Healthcare System,Ann Arbor, MI; ${ }^{5}$ Division of General Medical Disciplines, Stanford University, Stanford, CA
}

\begin{abstract}
Spinal cord injury (SCI) care is a high priority for the Veterans Health Administration (VHA). Aging Veterans, new cases of SCI from recent conflicts, and increasing numbers of women Veterans have likely changed the profile of the VHA SCI population. This study characterizes the current Veteran population with SCI with emphasis on healthcare utilization and women Veterans. We analyzed VHA administrative data from 2002-2003 and 2007-2008, analyzing composition, demographics, and healthcare use. The population is mostly male (>97\%) and largely between 45 and 64 years old. Over $30 \%$ are over the age of 65 . They are frequent users of healthcare, with an average of 21 visits per year. Women Veterans with SCI form a small but distinct subpopulation, being younger and less likely to be married and having a higher burden of disease. We must understand how the VHA population with SCI is changing to anticipate and provide the best care for these complex patients.
\end{abstract}

Key words: aging population, chronic diseases, demographics, high utilization, paralysis, quality of life, spinal cord injury, Veterans, Veterans Health Administration, women's health.

\section{INTRODUCTION}

Spinal cord injury (SCI) has a profound effect on the injured person, close family members, and society as a whole. Between 231,000 and 311,000 people in the United States are living with SCI [1]. There are roughly 42,000 Veterans with SCI [2]; therefore, approximately one in five people with SCI in the United States are Veterans. About 25,000 Veterans with SCI receive their care from the Veterans Health Administration (VHA) [3]. The majority of Veterans with SCI have longstanding injuries. The characteristics of chronic injuries are not well represented by the available literature, which emphasizes the patterns of acutely injured individuals [4-6]. Thus, studying Veterans with SCI provides an ideal setting in which to characterize the clinical profile of individuals with chronic SCI.

The population of Veterans with SCI has undergone substantial changes over the last 40 years. After the Vietnam war, the number of Veterans with SCI increased, and there was a national effort to better understand SCI and its sequelae [7]. VHA was a leader in SCI care, with resultant remarkable achievements. It instituted fellowship

Abbreviations: BIRLS $=$ Beneficiary Identification Records Locator Subsystem; CCS = Clinical Classification Software; FY = fiscal year; ICD-9-CM = International Classification of Diseases, 9th Revision, Clinical Modification; NPCD = National Patient Care Database; SCI = spinal cord injury; VA = Department of Veterans Affairs; VHA = Veterans Health Administration.

*Address all correspondence to Catherine M. Curtin, MD; VA Palo Alto Health Care System-Rehabilitation Research and Development, 770 Welch Rd, Suite 400, Palo Alto, CA 94304. Email: curtincatherine@yahoo.com http://dx.doi.org/10.1682/JRRD.2010.11.0220 
programs focused on specialized training for comprehensive SCI care and established specialized SCI centers [8]. This improved SCI care has resulted in many Veterans aging with their SCIs and thus facing new medical challenges, such as shoulder arthritis and cardiovascular disease [9]. The composition of the Veteran population with SCI in VHA is also affected by an influx of new SCI injuries from current conflicts and an increase in the number of women in the military. Woman Veterans with SCI have unique healthcare needs, such as reproductive health and osteoporosis management [10]. A clear understanding of how the VHA SCI population is evolving over time is a high priority for caregivers and the healthcare system. Caregivers need to recognize emerging health needs related to living with SCI, and the system must understand the implications of these changes in order to optimize the allocation of scarce resources.

This descriptive study's goal is to provide an overview of the Veteran SCI population that uses VHA. This study characterizes demographics and use of healthcare among female and male Veterans with SCI and assesses whether the composition of the current Veteran SCI population differs from the SCI population that used VHA prior to the most recent conflicts in Iraq and Afghanistan.

\section{METHODS}

\section{Overview}

Data from the VHA National Patient Care Database (NPCD) were selected for analysis. This Department of Veterans Affairs (VA) database contains administrative and clinical data on inpatient and outpatient care, including visit dates, diagnoses, procedures, and patient demographic information. We performed descriptive analyses using two time periods: fiscal years (FY) 2002-2003 and FY2007-2008. The analyses assessed Veterans' demographic characteristics (age, race, marital status), injury status (paraplegia, quadriplegia, or unspecified), diagnoses (based on International Classification of Diseases, 9th Revision, Clinical Modification [ICD-9-CM] diagnoses), and utilization patterns (based on clinic type codes). We included 2 years in each period because prior clinical work found that it took a 2-year interval to capture diagnoses for the majority of patients with SCI. We compared two time periods in order to capture secular shifts, including those associated with the recent conflicts in Iraq and Afghanistan.

\section{Study Cohorts, 2002-2003 and 2007-2008}

Using the NPCD outpatient and inpatient files, we first identified patients with SCI using the ICD-9-CM diagnosis codes (3440x, 3441, 806x, 9072, 952x). We reviewed all the diagnostic codes listed for each patient and excluded those patients with other neurologic diagnoses, such as multiple sclerosis, that could result in paralysis (33524, 33520, 340, 341x). We included only those who had a diagnosis of SCI from clinic stops where the patient was seen face-to-face by a clinician (i.e., not a laboratory, telephone, or radiology visit). In a sensitivity analysis, we determined that less than 5 percent had only one visit with an SCI diagnosis; this reassured us that our decision to count patients with only a single instance of an SCI diagnosis as having SCI is unlikely to introduce many instances, if any, of patients without SCI into our cohort. Additionally, we reviewed the NPCD inpatient files and identified a small cohort of patients with SCI who had no outpatient visits in the 2-year period.

Using the Means Test Indicator variable, we identified those individuals in the cohort who were not Veterans and excluded them from the database (385 and 613 civilians with SCI in FY2002-2003 and FY2007-2008, respectively, were removed). The Means Test Indicator variable reflects Veteran's status. The Veteran value was consistent across all records in 93 percent of the patients. Patients with discrepant means test values were classified as Veterans if more than 50 percent of their records listed them as Veterans. We resolved inconsistent data by obtaining the most frequent value or the latest value if patients had visits with tied values. We excluded Veterans if they had nonsensical date of birth (2 Veterans). Since sex was a stratification variable, we also excluded those with discrepant sex (0.2\%), i.e., with different sex listed in different administrative records.

\section{Variables}

We used the most frequent race recorded. If there was a tie, we used the race that was least represented within the VA system. We chose this approach because minority race is more likely to be underrepresented and/or missing in administrative data [11]. To minimize unknown values for race, we checked if patients with unknown values had a known race value in FYs 2000 through 2009. Although we were able to replace some unknown values, the percentage of unknowns was still substantial (FY20022003: 17\%; FY2007-2008: 20\%). VHA administrative 
data have a high proportion of individual records with missing race values [12].

Age was calculated using the date of birth and the beginning of each time frame (i.e., October 1, 2002, and October 1, 2007). Disease categories were defined using the Agency for Healthcare Research and Quality Clinical Classifications Software (CCS) for ICD-9-CM. The CCS is a tool for clustering patient diagnoses into a manageable number of clinically meaningful categories. CCS enables us to group conditions and procedures without having to sort through thousands of codes. For this study, we used the multilevel CCS, which places diseases into 18 general categories. We excluded the diagnoses for SCI from the diseases of the nervous system and sense organs category (CCS level 1 category 6, ICD-9 codes: 3440x, 3441 ) and injury and poisoning (CCS level 1 category 16, ICD-9 codes: 806x, 9072, 952x), leaving other neurological and sense organ conditions as well as other injury and poisoning in this category [13-14]. We defined the place of primary service by determining where patients received care (parent station and substation) most frequently in the VHA hub and spoke system for the two cohorts. The hub and spokes are designations by the VHA for specialized SCI care. A hub is an SCI center with a multidisciplinary team that offers primary and specialty SCI care; a spoke is a support clinic that provides primary care for patients with SCI [2].

Mortality information was obtained from the Beneficiary Identification Records Locator Subsystem (BIRLS) death file, which is the Veterans Benefits Administration database containing records of Veterans known to be deceased and is updated monthly. Death dates come from multiple sources, including reports from family members applying for death benefits, VHA hospitals, and the VA National Cemetery Administration.

\section{RESULTS}

There were 23,314 Veterans in the FY2002-2003 SCI cohort and 19,296 in the FY2007-2008 SCI cohort. The crude mortality rate for the two cohorts was 57 and 42 deaths per 1,000 people per year, respectively. From the FY2002-2003 cohort, 43 percent were not members of the FY2007-2008 cohort (i.e., they were not identified as VHA users with SCI in FY2007-2008). Of them, half had died. Of the remainder, 74 percent had outpatient visits in FY2007-2008 for counseling, prescription refill issues, conditions and factors influencing health, and fitting of orthopedic device, and a smaller number had visits in FY2004 to FY2006. Only 1,184 of those missing from FY2007-2008 were not accounted for with other visits in FY2004 to FY2008 or within the BIRLS file. Most of the cohort members were identified through outpatient encounters. Only 8 percent of each cohort had an inpatient encounter as the only source of an SCI diagnosis. These patients were all discharged within the study period, and most of them had outpatient visits within the study periods. They were not captured in the outpatient cohort because there was no SCI diagnosis associated with those visits (approximately 80\%). The remainder of inpatients had an outpatient visit in the later years.

The majority of our cohort was between the ages of 45 and 64 . The mean age in both cohorts was 60 years, with 30 percent of patients older than 65 (Figure). Women with SCI were a small subpopulation representing less than 3 percent of the cohorts. This contrasts with the general SCI population, in which women represent 19 percent [1]. Women were younger than men $(p<$ 0.001) in both cohorts (Figure), having a mean age of 51 versus 59 in FY2002-2003 and 52 versus 60 in FY20072008.

The majority (FY2002-2003: 66\%; FY2007-2008: $61 \%$ ) of the population was white, 17 percent was black, and other races (American Indian and Asian) totaled less than 2 percent. The latter cohort had a higher percentage of unknown race values. Men were more likely to be married than women; 47 versus 32 percent in FY2002-2003

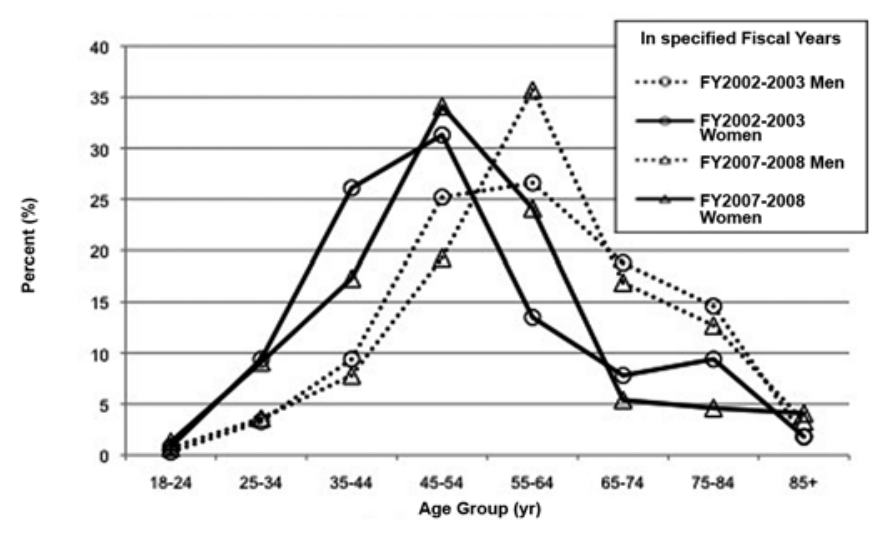

Figure.

Mean age distribution of women and men with spinal cord injury by fiscal year (FY). 
and 45 versus 29 percent in FY2007-2008 $(p<0.001$, Table 1).

More than 50 percent had paraplegia in both cohorts, approximately 37 (FY2002-2003) and 39 percent (FY2007-2008) had quadriplegia, and a small percentage had an unspecified injury. Differences between the sexes were observed for the level of injury, with a lower prevalence of quadriplegia in the female population (Table 1). This population also had a greater number of unspecified injuries.

We also analyzed the diagnoses associated with medical care. In both study periods, the average number of comorbid conditions for a patient with SCI was 15 . We found that the average number of comorbid conditions did not change between the two cohort periods. We analyzed both the outpatient and inpatient data by patient and encounter/stay level. For the patient level, we assessed each patient's diagnoses and sorted them by CCS category. For the encounter/stay level, we assessed what diagnoses were associated with outpatient encounters and inpatient stays, giving an indication of the diagnoses resulting in healthcare utilization. Looking at the outpatient patient-level diagnoses, we found differences between the men and women, but the top four conditions for all were

1. Disease of the nervous system and sense organs (ICD9 codes: 36x [eye disorders], 389.18 [hearing loss], 781.0 [abnormal involuntary movement]).

2. Diseases of the genitourinary system (596.54 [neurogenic bladder], 599.0 [urinary tract infection], 607.84 [impotence]).

3. Diseases of the digestive system (525x [diseases of teeth and supporting structures], 564.81 [neurogenic bowel], 530.81 [esophageal reflux], 521.00 [dental caries]).

4. Diseases of the musculoskeletal system and connective tissue (724x [disorders of the back, i.e., back pain], 715.90 [osteoarthrosis], 719.41 [pain in joint, shoulder region]) (Table 2).

In the diseases of the nervous system and sense organs category, the majority of diagnoses (70\%) were related to vision/eye disorders (after excluding SCI diagnosis). VHA provides eye and audiology examinations for Veterans, which likely explains the high number of visits for this category. We also assessed diagnoses at the encounter level and found similar diagnostic categories, except for in mental health, which generated the most

Table 1.

Attributes of Veterans with SCI in specific fiscal years.

\begin{tabular}{|c|c|c|c|c|c|c|}
\hline \multirow{2}{*}{ Characteristics } & \multicolumn{3}{|c|}{ FY2002-2003 } & \multicolumn{3}{|c|}{ FY2007-2008 } \\
\hline & Female & Male & Total & Female & Male & Total \\
\hline$n$ & 629 & 22,685 & 23,314 & 495 & 18,801 & 19,296 \\
\hline \multicolumn{7}{|l|}{ Marital Status (\%) } \\
\hline Married & 32 & 46 & 46 & 29 & 45 & 45 \\
\hline Divorced & 28 & 22 & 22 & 30 & 24 & 24 \\
\hline Never Married/Single & 23 & 17 & 17 & 24 & 18 & 18 \\
\hline Widowed & 8 & 5 & 5 & 9 & 5 & 5 \\
\hline Unknown & 9 & 10 & 10 & 7 & 8 & 8 \\
\hline \multicolumn{7}{|l|}{ Race (\%) } \\
\hline White & 67 & 66 & 66 & 61 & 61 & 61 \\
\hline Black & 13 & 16 & 16 & 15 & 17 & 17 \\
\hline Other & 1 & 1 & 1 & 3 & 2 & 2 \\
\hline Unknown & 19 & 17 & 17 & 21 & 20 & 20 \\
\hline \multicolumn{7}{|l|}{ SCI Category (\%) } \\
\hline Paraplegia & 56 & 55 & 55 & 59 & 54 & 54 \\
\hline Tetraplegia & 30 & 37 & 37 & 32 & 39 & 38 \\
\hline Unspecified & 13 & 8 & 8 & 9 & 7 & 8 \\
\hline \multicolumn{7}{|c|}{$\begin{array}{l}\text { This table is descriptive; } p \text {-values are not shown. } \\
\text { Unspecified value in SCI category: patients with diagnosis that had codes where type of SCI was unclear or who had equal number of diagnosis that were both for } \\
\text { paraplegia and tetraplegia. } \\
\text { FY = fiscal year, SCI = spinal cord injury. }\end{array}$} \\
\hline
\end{tabular}


Table 2.

Disease burden at patient and encounter level in Veterans with SCI (outpatient diagnoses) in full cohort.

\begin{tabular}{|c|c|c|c|c|c|c|c|c|c|c|c|c|}
\hline \multirow{3}{*}{ Disease Category ${ }^{*}$} & \multicolumn{6}{|c|}{$\begin{array}{l}\text { FY2002-2003 } \\
\end{array}$} & \multicolumn{6}{|c|}{ FY2007-2008 } \\
\hline & \multicolumn{3}{|c|}{ Patient Level } & \multicolumn{3}{|c|}{ Encounter Level } & \multicolumn{3}{|c|}{ Patient Level } & \multicolumn{3}{|c|}{ Encounter Level } \\
\hline & Female & Male & Total & Female & Male & Total & Female & Male & Total & Female & Male & Total \\
\hline$n$ & 591 & 20,692 & 21,283 & 27,673 & 737,416 & 765,089 & 474 & 17,428 & 17,902 & 24,446 & 676,746 & 701,192 \\
\hline $\begin{array}{l}\text { Diseases of nervous } \\
\text { system and sense organs }^{\dagger}(\%)\end{array}$ & 71 & 66 & 69 & 15 & 12 & 12 & 72 & 69 & 71 & 9 & 10 & 10 \\
\hline $\begin{array}{l}\text { Diseases of genitourinary } \\
\text { system (\%) }\end{array}$ & 70 & 64 & 66 & 8 & 11 & 11 & 77 & 69 & 71 & 9 & 12 & 12 \\
\hline $\begin{array}{l}\text { Diseases of digestive } \\
\text { system (\%) }\end{array}$ & 64 & 61 & 64 & 9 & 10 & 10 & 69 & 68 & 70 & 9 & 11 & 11 \\
\hline $\begin{array}{l}\text { Diseases of musculo- } \\
\text { skeletal system (\%) }\end{array}$ & 74 & 60 & 63 & 17 & 12 & 12 & 75 & 64 & 66 & 15 & 12 & 12 \\
\hline $\begin{array}{l}\text { Diseases of circulatory } \\
\text { system (\%) }\end{array}$ & 48 & 57 & 59 & 7 & 10 & 10 & 55 & 62 & 63 & 7 & 10 & 10 \\
\hline $\begin{array}{l}\text { Endocrine, nutritional, and } \\
\text { metabolic diseases and } \\
\text { immunity (\%) }\end{array}$ & 51 & 49 & 51 & 7 & 8 & 8 & 57 & 61 & 63 & 7 & 9 & 9 \\
\hline $\begin{array}{l}\text { Diseases of skin and subcu- } \\
\text { taneous tissue (\%) }\end{array}$ & 41 & 46 & 47 & 4 & 8 & 7 & 43 & 47 & 48 & 3 & 7 & 7 \\
\hline Mental illness (\%) & 56 & 44 & 46 & 18 & 14 & 14 & 62 & 52 & 54 & 27 & 14 & 14 \\
\hline $\begin{array}{l}\text { Diseases of respiratory } \\
\text { system (\%) }\end{array}$ & 45 & 33 & 35 & 3 & 3 & 3 & 42 & 31 & 32 & 3 & 3 & 3 \\
\hline Injury and poisoning (\%) & 40 & 31 & 33 & 3 & 3 & 3 & 39 & 29 & 30 & 3 & 3 & 3 \\
\hline $\begin{array}{l}\text { Residual codes, } \\
\text { unclassified (\%) }\end{array}$ & 29 & 29 & 30 & 2 & 2 & 2 & 27 & 30 & 31 & 1 & 1 & 1 \\
\hline $\begin{array}{l}\text { Infectious and parasitic } \\
\text { diseases (\%) }\end{array}$ & 24 & 23 & 25 & 2 & 2 & 2 & 26 & 24 & 25 & 2 & 2 & 2 \\
\hline $\begin{array}{l}\text { Symptoms, signs, and } \\
\text { ill-defined conditions and } \\
\text { factors influencing health } \\
\text { status (\%) }\end{array}$ & 33 & 21 & 22 & 2 & 1 & 1 & 26 & 17 & 18 & 1 & 1 & 1 \\
\hline Neoplasms (\%) & 22 & 18 & 19 & 2 & 3 & 3 & 20 & 20 & 20 & 2 & 3 & 3 \\
\hline $\begin{array}{l}\text { Diseases of blood and } \\
\text { blood-forming organs (\%) }\end{array}$ & 12 & 11 & 11 & 1 & 1 & 1 & 14 & 14 & 15 & 1 & 2 & 2 \\
\hline $\begin{array}{l}\text { Complications of preg- } \\
\text { nancy, childbirth, and } \\
\text { puerperium }^{\ddagger}(\%)\end{array}$ & 1 & 0 & 0 & 0 & 0 & 0 & 1 & 0 & 0 & 0 & 0 & 0 \\
\hline \multicolumn{13}{|c|}{$\begin{array}{l}\text { "Disease categories were defined using multilevel Healthcare Research and Quality Clinical Classifications Software (CCS, 2008) for International Classification } \\
\text { of Diseases, 9th Revision, Clinical Modification; all diagnoses in each encounter were analyzed. Data on frequency of categories by sex are descriptive; } p \text {-values } \\
\text { are not shown. "Patient level” columns provide percent of patients with condition. "Encounter level” columns provide percent of encounters at which care was pro- } \\
\text { vided for condition. } \\
{ }^{\dagger} \text { SCI diagnosis from diseases of nervous system and sense organs categories were omitted as well as e and v codes (non-disease-related conditions). }\end{array}$} \\
\hline
\end{tabular}

outpatient encounters (Table 2). This population had many face-to-face encounters in the 2-year periods (approximately 700,000).

After analyzing the principal diagnosis for which patients were being admitted, we found similar results for both the person level and stay level (Table 3). The most common conditions for which patients were admitted were similar to the conditions seen in the outpatient encounters, except that more patients were being admitted for skin and subcutaneous tissue problems (ICD-9-CM codes: 707x [chronic ulcer], 682x [cellulitis and abscess], 686 [local infections of skin and subcutaneous tissue]). 
Table 3.

Disease burden at patient and stay level in Veterans with SCI (impatient diagnoses) in subset who used inpatient services.

\begin{tabular}{|c|c|c|c|c|c|c|c|c|c|c|c|c|}
\hline \multirow{3}{*}{ Disease Category ${ }^{*}$} & \multicolumn{6}{|c|}{$\begin{array}{l}\text { FY2002-2003 } \\
\end{array}$} & \multicolumn{6}{|c|}{$\begin{array}{l}\text { FY2007-2008 } \\
\end{array}$} \\
\hline & \multicolumn{3}{|c|}{ Patient Level } & \multicolumn{3}{|c|}{ Stay Level } & \multicolumn{3}{|c|}{ Patient Level } & \multicolumn{3}{|c|}{ Stay Level } \\
\hline & Female & Male & Total & Female & Male & Total & Female & Male & Total & Female & Male & Total \\
\hline$n$ & 314 & 12,267 & 12,581 & 796 & 31,708 & 32,504 & 233 & 9,892 & 10,125 & 612 & 26,357 & 26,969 \\
\hline $\begin{array}{l}\text { Diseases of genitourinary } \\
\text { system (\%) }\end{array}$ & 21 & 21 & 21 & 12 & 12 & 12 & 20 & 22 & 22 & 11 & 12 & 13 \\
\hline $\begin{array}{l}\text { Diseases of skin and } \\
\text { subcutaneous tissue (\%) }\end{array}$ & 14 & 15 & 17 & 5 & 10 & 10 & 12 & 14 & 16 & 6 & 9 & 9 \\
\hline $\begin{array}{l}\text { Diseases of circulatory } \\
\text { system (\%) }\end{array}$ & 8 & 17 & 15 & 8 & 8 & 8 & 9 & 16 & 14 & 5 & 7 & 7 \\
\hline $\begin{array}{l}\text { Diseases of musculoskeletal } \\
\text { system (\%) }\end{array}$ & 20 & 13 & 13 & 10 & 7 & 7 & 15 & 13 & 13 & 8 & 6 & 6 \\
\hline $\begin{array}{l}\text { Diseases of digestive } \\
\text { system (\%) }\end{array}$ & 12 & 12 & 12 & 6 & 6 & 6 & 14 & 12 & 12 & 7 & 6 & 6 \\
\hline Injury and poisoning (\%) & 9 & 11 & 11 & 6 & 5 & 5 & 8 & 11 & 12 & 5 & 6 & 6 \\
\hline $\begin{array}{l}\text { Diseases of respiratory } \\
\text { system (\%) }\end{array}$ & 11 & 8 & 11 & 5 & 6 & 6 & 11 & 7 & 11 & 6 & 6 & 6 \\
\hline $\begin{array}{l}\text { Diseases of nervous } \\
\text { system and sense organs }{ }^{\dagger}(\%)\end{array}$ & 18 & 10 & 10 & 7 & 4 & 5 & 12 & 8 & 8 & 6 & 4 & 4 \\
\hline Mental illness (\%) & 11 & 8 & 8 & 3 & 4 & 4 & 11 & 7 & 7 & 6 & 4 & 4 \\
\hline Neoplasms (\%) & 7 & 8 & 8 & 3 & 4 & 4 & 7 & 7 & 7 & 4 & 4 & 4 \\
\hline $\begin{array}{l}\text { Endocrine, nutritional, and } \\
\text { metabolic diseases and } \\
\text { immunity (\%) }\end{array}$ & 5 & 5 & 5 & 3 & 2 & 2 & 3 & 4 & 4 & 2 & 2 & 2 \\
\hline $\begin{array}{l}\text { Infectious and parasitic } \\
\text { diseases (\%) }\end{array}$ & 3 & 4 & 4 & 1 & 2 & 2 & 3 & 4 & 4 & 2 & 2 & 2 \\
\hline $\begin{array}{l}\text { Symptoms, signs, and } \\
\text { ill-defined conditions and } \\
\text { factors influencing health } \\
\text { status (\%) }\end{array}$ & 6 & 3 & 3 & 3 & 1 & 1 & 4 & 3 & 3 & 2 & 1 & 1 \\
\hline $\begin{array}{l}\text { Diseases of blood and } \\
\text { blood-forming organs (\%) }\end{array}$ & 3 & 2 & 2 & 1 & 1 & 1 & 2 & 2 & 2 & 1 & 1 & 1 \\
\hline $\begin{array}{l}\text { Residual codes, } \\
\text { unclassified (\%) }\end{array}$ & 0 & 1 & 1 & 0 & 1 & 1 & 0 & 1 & 1 & 0 & 1 & 1 \\
\hline $\begin{array}{l}\text { Complications of preg- } \\
\text { nancy, childbirth, and } \\
\text { puerperium (\%) }\end{array}$ & 0 & 0 & 0 & 0 & 0 & 0 & 0 & 0 & 0 & 0 & 0 & 0 \\
\hline $\begin{array}{l}{ }^{*} \text { Disease categories were defined } \\
\text { of Diseases, 9th Revision, Clinica } \\
\text { shown. "Patient level" columns p } \\
\text { condition. } \\
{ }^{\dagger} \text { SCI diagnosis from diseases of n } \\
25 \% \text {, FY2007-2008 = 28\%). Thi } \\
\text { FY = fiscal year, SCI = spinal cor }\end{array}$ & $\begin{array}{l}\text { d using mu } \\
\text { cal Modific } \\
\text { provide pe } \\
\text { nervous sy } \\
\text { is has effec } \\
\text { ord injury. }\end{array}$ & $\begin{array}{l}\text { tilevel } \mathrm{H} \\
\text { tion; prir } \\
\text { cent of pa } \\
\text { tem and s } \\
\text { ton total }\end{array}$ & $\begin{array}{l}\text { lthcare R } \\
\text { ary diagn } \\
\text { ients with } \\
\text { ase organs } \\
\text { stay leve }\end{array}$ & $\begin{array}{l}\text { search an } \\
\text { is in each } \\
\text { ondition. } \\
\text { ategories }\end{array}$ & $\begin{array}{l}\text { Quality C } \\
\text { stay was a } \\
\text { "Stay leve } \\
\text { were omitt }\end{array}$ & $\begin{array}{l}\text { inical Cla } \\
\text { alyzed. D } \\
\text { d columns } \\
\text { d as well a }\end{array}$ & $\begin{array}{l}\text { ssifications } \\
\text { ata on frequ } \\
\text { provide pe } \\
\text { as e and v c }\end{array}$ & $\begin{array}{l}\text { Software } \\
\text { ency of ca } \\
\text { cent of in } \\
\text { des (non- }\end{array}$ & $\begin{array}{l}\text { CCS, } 200 \\
\text { egories by } \\
\text { atient stay } \\
\text { lisease-rel }\end{array}$ & $\begin{array}{l}\text { for Interr } \\
\text { sex are de } \\
\text { at which }\end{array}$ & $\begin{array}{l}\text { hational Cl } \\
\text { scriptive; } \\
\text { care was } P \\
\text { ons) (FY2 }\end{array}$ & $\begin{array}{l}\text { ssification } \\
\text { values not } \\
\text { ovided for } \\
2-2003=\end{array}$ \\
\hline
\end{tabular}

The patients in this cohort frequently utilized VHA, with an average of 21 visits per year. The VHA spinal cord system of specialty care had a better capture of these patients in the later years, with 86 percent of the group receiving most of their care at a designated site: a hub or a spoke (Table 4). More than 50 percent of the Veterans had visits to an SCI clinic (stop code 210).

\section{DISCUSSION}

Over time, many factors have influenced the Veteran SCI population [15], such as changes in injury mechanisms, higher numbers of women in the military, and increased life expectancy after injury, and these factors change the composition and medical needs of this group. 
This study presents a description of the current Veteran population with SCI and the ways that the recent population differs from the cross-section of patients with SCI who were using VHA in FY2002-2003. Our work provides insights into future clinical challenges.

We did not find an increase in the number of Veterans with SCI over the time periods studied. This is consistent with other studies that have shown that recent conflicts have resulted in a few hundred new SCIs [16]. This relatively low rate of SCI may be because of changes in injury patterns secondary to the advent of body armor and better acute care on the battlefield [17]. The FY2007-2008 Veteran SCI cohort was smaller secondary to the loss of patients. Half of those lost from the FY2002-2003 cohort had died in the ensuing 5 years [18]. Most of the remaining Veterans not captured in FY2007-2008 had visits not specific to SCI care. Though these patients did not have SCI diagnoses, they continued to be high users of care, with an average of 20 face-toface visits per year.

Women Veterans are particularly important because they represent one of the fastest growing groups of Veterans. Understanding women Veterans with SCI is important because VHA has initiated a women's health program to optimize women's experience in the VHA healthcare system [19]. We found that only a small proportion of Veterans with SCI are women, but these women may face different challenges than their male counterparts. A significantly lower percentage of women

Table 4.

Percent of Veterans with SCI who received care in SCI centers.

\begin{tabular}{|c|c|c|c|c|c|c|}
\hline \multirow{2}{*}{$\begin{array}{l}\text { Facility } \\
\text { Type }\end{array}$} & \multicolumn{3}{|c|}{ FY2002-2003 } & \multicolumn{3}{|c|}{ FY2007-2008 } \\
\hline & Female & Male & Total & Female & Male & Total \\
\hline $\bar{n}$ & 629 & 22,685 & 23,314 & 495 & 18,801 & 19,296 \\
\hline Hub (\%) & 40 & 42 & 42 & 45 & 47 & 47 \\
\hline Spoke (\%) & 36 & 38 & 38 & 39 & 39 & 39 \\
\hline $\begin{array}{l}\text { Not Hub or } \\
\text { Spoke }^{*}(\%)\end{array}$ & 24 & 20 & 20 & 16 & 14 & 14 \\
\hline $\begin{array}{l}\text { SCI Clinic }{ }^{\dagger} \\
(\%)\end{array}$ & 57 & 52 & 52 & 68 & 65 & 65 \\
\hline \multicolumn{7}{|c|}{$\begin{array}{l}{ }^{*} \text { Facilities that were not SCI center (hub) or did not have SCI care team (spoke). } \\
\text { †SCI clinic: Visits that had stop codes of } 210 \text {, specific for SCI (can be hub ol } \\
\text { spoke). } \\
\text { FY = fiscal year, SCI = spinal cord injury. }\end{array}$} \\
\hline
\end{tabular}

with SCI than men were married, a finding also seen in the general Veteran population [20]. The causes of the lower marital rates are likely multifactorial, but this difference is important because marital status is linked to life satisfaction after injury [21]. Providers may want to pay special attention to the social support available to these women [20,22]. Women with SCI were younger than the male group and had a different distribution of medical diagnoses (Figure and Tables 2-3). Indeed, women had higher rate of diagnoses in 13 of the 18 categories. Women Veteran VHA patients in some studies have had a particularly heavy burden of illness, and the findings for women Veterans with SCI seem to parallel these findings [23]. Medical interventions may need to be tailored specifically to women's needs. For example, musculoskeletal conditions affect three-quarters of women with SCI; any necessary prosthetic devices must be adjusted to women's lower average size. Similarly, genitourinary conditions affect three-quarters of women with SCI, making it important to provide access to gynecology and urological services with the capacity for sensitive exams on women with SCI. For the VHA's women's health initiative to be successful, VHA will need to care for the unique subpopulations of women and provide care focused on their specialized medical and social needs.

Like the general VHA population, Veterans with SCI are aging. The percentage of elderly patients with SCI was sizable, with more than 30 percent over the age of 64 . This elderly group likely consists of two groups: people with chronic SCI from injuries sustained many years ago and people with recent-onset SCI related to traumas such as falls in old age [24]. Meanwhile, the highest proportion of SCI patients are in the 55 to 64 age group; in another decade they will reach old age, suggesting that VHA should prepare for a coming wave of elderly Veterans with SCI. Aging adds new challenges to the care of all Veterans, but in particular to patients with SCI [25]. Older people with SCI require the increased medical care expected with aging, and they have additional needs such as adaptation to durable equipment and increased attendant time. With aging, one often has to address concurrent conditions such as heart and lung disease or arthritis, which make transfers and wheelchair propulsion much more challenging. These older patients have increased complexity of care and will have increased costs. Currently, SCI is the most costly of all chronic diseases [26]. The average yearly healthcare and living expenses and 
the estimated lifetime costs directly attributable to SCI vary anywhere from $\$ 0.7$ to $\$ 3.2$ million according to severity of injury [1,27]. In the VA system, half the costs of care from a sample of SCI patients came from inpatient admissions, many of which are the result of rehospitalizations for secondary conditions [28]. Even though this population is decreasing in size, it is reasonable to anticipate that as the population with SCI ages, they may continue to increase costs to the healthcare system.

An older population also has more secondary health problems, placing more challenges on the clinicians caring for them. Currently, Veterans with SCI are high users of care, with an average of 21 visits per year. This study assessed the diagnoses associated with those clinic visits and found multiple associated medical problems (Table 3). Diseases of the genitourinary, digestive, and musculoskeletal systems were frequent categories of diagnoses associated with visits. Musculoskeletal complaints are critical because they have a major impact on healthrelated quality of life, and interventions may mitigate severity [29]. For example, lightweight wheelchairs and power-assist wheels may preserve shoulder function and prevent loss of independence [30]. Other diseases of aging are also becoming more prevalent, with cancer and heart disease now leading causes of mortality in this population [15]. The increase of these concomitant diagnoses could stress the physician resources that care for these complex patients. During an SCI clinic visit, a wide variety of SCI-specific issues, such as autonomic dysreflexia, skin integrity, and pulmonary mechanics, must be addressed. To address the growing complexity of these patients, the SCI team may benefit from supplementation with other specialties to assist the physiatrist [31]. One solution is for the physiatrist to direct a team that includes an orthopedist, urologist, social worker, therapist, cardiologist, etc. This multidisciplinary model would be similar to that used to treat children with cystic fibrosis [32]. This type of multidisciplinary team would align well with the new VA initiative to foster a patientcentered medical home approach. This program will implement primary care teams to direct integrated interdisciplinary patient-centered care [33]. Although the SCI system of care already incorporates prevention and early detection of complications of SCI with multidisciplinary teams providing annual comprehensive evaluations, adding specialized physicians to the teams would greatly enhance the quality of care.

VHA is in a unique position to lead and innovate the care of patients with SCI because most Veterans with SCI are captured by the specialized SCI clinics (hubs or spokes). Novel approaches in anticipation of future resource needs could be implemented within VHA to meet the specialized needs of this population.

\section{Limitations}

This study represents two cross-sectional pictures of the SCI population. Since this is a dynamic population, with patients entering and leaving VHA, change will continue. This study has the problems encountered with all administrative data, including risk of under- and miscoding of diagnoses by providers. We initially wanted to augment the NPCD data with the SCI Registry. However, only 50 percent of our NPCD cohorts were in the Registry and missing data rates were high for variables of interest to us (e.g., type of injury was $98 \%$ indeterminate for our cohorts). The low concordance between the Registry and our NPCD-generated cohort is consistent with Smith et al.'s study evaluating different administrative VA data sources (including the Registry) in SCI research. They had roughly 30 percent missing and recommended using a cohort constructed like this study for research evaluating SCI system of care [34]. Finally, this study included only those Veterans with SCI who used VHA, so results cannot be generalized to Veterans with SCI who do not use VHA or to civilians with SCI. Even with these limitations, it is important to understand this population now to anticipate future needs.

\section{Strengths}

This study represents the universe of Veterans with SCI who used the VHA system during FY2002-2003 and FY2007-2008 and thus is not subject to some of the selection bias issues inherent in other study designs. The two time points present opportunity to examine secular trends. This study separately examines women Veterans, who represent an emerging population for VHA [35]. Finally, this study includes a large number of older patients who may have had SCI for many years, thus making an important contribution to literature that tends to focus more on people with recent injuries.

\section{CONCLUSIONS}

Veterans with SCI are an older population and have multiple medical diagnoses. Women Veterans with SCI are a unique subpopulation who are significantly younger, have less social support, and a have higher burden 
of disease. The increasing complexity of the VHA SCI population will place new demands on the healthcare system. We hope that this study will provide a foundation to help direct the focus of future research and clinical care.

\section{ACKNOWLEDGMENTS}

\author{
Author Contributions: \\ Study concept and design: C. M. Curtin. \\ Acquisition of data: P. A. Suarez. \\ Analysis and interpretation of data: C. M. Curtin, S. M. Frayne. \\ Drafting of manuscript: C. M. Curtin, L. A. Di Ponio, S. M. Frayne. \\ Critical revision of manuscript for important intellectual content: \\ L. A. Di Ponio, S. M. Frayne. \\ Statistical analysis: P. A. Suarez. \\ Administrative, technical, or material support: P. A. Suarez.
}

Financial Disclosures: The authors have declared that no competing interests exist.

Funding/Support: This material was based on work supported by a VHA Rehabilitation Research and Development Career Development Award (grant B647 to Dr. Curtin).

Additional Contributions: We gratefully acknowledge Eric A. Berg for his technical contribution.

Disclaimer: The views expressed in this article are those of the authors and do not necessarily represent the views of the VA.

\section{REFERENCES}

1. Spinal cord injury facts and figures at a glance [Internet]. Birmingham (AL): National SCI Statistical Center; 2010 [updated 2010 Feb; cited 2011 Jan]. Available from: https://www.nscisc.uab.edu/public content/pdf/Facts\%20and \%20Figures\%20at\%20a\%20Glance\%202010.pdf

2. VA fact sheet: VA and spinal cord injury [Internet]. Washington (DC): Department of Veterans Affairs; 2009 [updated 2009 Jan; cited 2011 Jun]. Available from: http://www.sci.va.gov

3. QUERI fact sheet: Spinal cord injury [Internet]. Washington (DC): VA Office of Research and Development; 2011 [updated 2011 Jun; cited 2010 Aug]. Available from: http://www.queri.research.va.gov/about/factsheets/ sci factsheet.pdf

4. Whiteneck GG, Charlifue SW, Frankel HL, Fraser MH, Gardner BP, Gerhart KA, Krishnan KR, Menter RR, Nuseibeh I, Short DJ, Silver JR. Mortality, morbidity, and psychosocial outcomes of persons spinal cord injured more than 20 years ago. Paraplegia. 1992;30(9):617-30.

PMID:1408338

http://dx.doi.org/10.1038/sc.1992.124
5. Kemp B, Thompson L. Aging and spinal cord injury: Medical, functional, and psychosocial changes. SCI Nurs. 2002;19(2):51-60. PMID:12510506

6. Lasfargues JE, Custis D, Morrone F, Carswell J, Nguyen T. A model for estimating spinal cord injury prevalence in the United States. Paraplegia. 1995;33(2):62-68. PMID:7753569 http://dx.doi.org/10.1038/sc.1995.16

7. Heyl HL. Federal programs for the care and study of spinal cord injuries. J Neurosurg. 1972;36(4):379-85.

PMID:4552146

http://dx.doi.org/10.3171/jns.1972.36.4.0379

8. Lin VW, Cardenas DD, Cutter NC, Frost FS, Hammond MC, Lindblom LB, Perkash I, Waters R, Woolsey RM. Spinal cord medicine: Principles and practice. New York (NY): Demos Medical; 2003.

9. Capoor LJ, Stein AB. Aging with spinal cord injury. Phys Med Rehabil Clin N Am. 2005;16:129-61.

PMID:15561548

http://dx.doi.org/10.1016/j.pmr.2004.06.016

10. Shackelford M, Farley T, Vines CL. A comparison of women and men with spinal cord injury. Spinal Cord. 1998;36(5):337-39. PMID:9601113 http://dx.doi.org/10.1038/sj.sc.3100510

11. Boehmer U, Kressin NR, Berlowitz DR, Christiansen CL, Kazis LE, Jones JA. Self-reported vs administrative race/ ethnicity data and study results. Am J Public Health. 2002;92(9):1471-72. PMID:12197976 http://dx.doi.org/10.2105/AJPH.92.9.1471

12. Sohn MW, Zhang H, Arnold N, Stroupe K, Taylor BC, Wilt TJ, Hynes DM. Transition to the new race/ethnicity data collection standards in the Department of Veterans Affairs. Popul Health Metr. 2006;4:7. PMID:16824220 http://dx.doi.org/10.1186/1478-7954-4-7

13. Clinical classifications software (CCS) [Internet]. Rockville (MD): Agency for Healthcare Research and Quality Healthcare Cost and Utilization Project; 2011 [updated 2011 Oct; cited 2010 Aug]. Available from: http://www.hcupus.ahrq.gov/toolssoftware/ccs/CCSUsersGuide.pdf

14. Frayne SM, Chiu VY, Iqbal S, Berg EA, Laungani KJ, Cronkite RC, Pavao J, Kimerling R. Medical care needs of returning veterans with PTSD: Their other burden. J Gen Intern Med. 2011;26(1):33-39. PMID:20853066 http://dx.doi.org/10.1007/s11606-010-1497-4

15. Fisher CG, Noonan VK, Dvorak MF. Changing face of spine trauma care in North America. Spine. 2006;31(11 Suppl):S2-8, discussion S36. PMID:16685231 http://dx.doi.org/10.1097/01.brs.0000217948.02567.3a

16. Weaver FM, Burns SP, Evans CT, Rapacki LM, Goldstein B, Hammond MC. Provider perspectives on soldiers with new spinal cord injuries returning from Iraq and Afghanistan. Arch Phys Med Rehabil. 2009;90(3):517-21. PMID:19254621 http://dx.doi.org/10.1016/j.apmr.2008.09.560 
17. Owens BD, Kragh JF Jr, Wenke JC, Macaitis J, Wade CE, Holcomb JB. Combat wounds in Operation Iraqi Freedom and Operation Enduring Freedom. J Trauma. 2008;64(2): 295-99. PMID:18301189 http://dx.doi.org/10.1097/TA.0b013e318163b875

18. Veterans care-Mission and service delivery structure, demographic trends, clinical programs in aging, research in aging [Internet]. Medicine Encyclopedia; 2010. Available from: http://medicine.jrank.org/pages/1803/Veterans-Care.html

19. Women veterans health care [Internet]. Washington (DC): Department of Veterans Affairs; 2010 [updated 2010 Jan 19; cited 2010 Oct 28]. Available from: http://www.publi chealth.va.gov/womenshealth

20. Frayne SM, Parker VA, Christiansen CL, Loveland S, Seaver MR, Kazis LE, Skinner KM. Health status among 28,000 women veterans. The VA Women's Health Program Evaluation Project. J Gen Intern Med. 2006;21(Suppl 3): S40-46. PMID:16637944 http://dx.doi.org/10.1111/j.1525-1497.2006.00373.x

21. Holicky R, Charlifue S. Ageing with spinal cord injury: The impact of spousal support. Disabil Rehabil. 1999; 21(5-6):250-57. PMID:10381237 http://dx.doi.org/10.1080/096382899297675

22. Post MW, De Witte LP, Van Asbeck FW, Van Dijk AJ, Schrijvers AJ. Predictors of health status and life satisfaction in spinal cord injury. Arch Phys Med Rehabil. 1998;79(4):395-401. PMID:9552104 http://dx.doi.org/10.1016/S0003-9993(98)90139-3

23. Brett KM, Burt CW. Utilization of ambulatory medical care by women: United States, 1997-98. Vital Health Stat 13. 2001;149(149):1-46. PMID:11478128

24. Jackson AB, Dijkers M, Devivo MJ, Poczatek RB. A demographic profile of new traumatic spinal cord injuries: Change and stability over 30 years. Arch Phys Med Rehabil. 2004;85(11):1740-48. PMID:15520968 http://dx.doi.org/10.1016/j.apmr.2004.04.035

25. Charlifue SW, Weitzenkamp DA, Whiteneck GG. Longitudinal outcomes in spinal cord injury: Aging, secondary conditions, and well-being. Arch Phys Med Rehabil. 1999;80(11): 1429-34. PMID:10569437 http://dx.doi.org/10.1016/S0003-9993(99)90254-X

26. Yu W, Ravelo A, Wagner TH, Phibbs CS, Bhandari A, Chen S, Barnett PG. Prevalence and costs of chronic conditions in the VA health care system. Med Care Res Rev. 2003;60(3 Suppl):146S-67S. PMID:15095551 http://dx.doi.org/10.1177/1077558703257000

27. DeVivo MJ. Causes and costs of spinal cord injury in the United States. Spinal Cord. 1997;35(12):809-13. PMID:9429259 http://dx.doi.org/10.1038/sj.sc.3100501

28. French DD, Campbell RR, Sabharwal S, Nelson AL, Palacios PA, Gavin-Dreschnack D. Health care costs for patients with chronic spinal cord injury in the Veterans Health Administration. J Spinal Cord Med. 2007;30(5): 477-81. PMID:18092564

29. Hitzig SL, Tonack M, Campbell KA, McGillivray CF, Boschen KA, Richards K, Craven BC. Secondary health complications in an aging Canadian spinal cord injury sample. Am J Phys Med Rehabil. 2008;87(7):545-55. PMID:18574346 http://dx.doi.org/10.1097/PHM.0b013e31817c16d6

30. Paralyzed Veterans of America Consortium for Spinal Cord Medicine. Preservation of upper limb function following spinal cord injury: A clinical practice guideline for healthcare professionals. J Spinal Cord Med. 2005;28(5):434-70. PMID:16869091

31. VA handbook 1176.1—SCI\&D systems of care procedures. Washington (DC): Veterans Health Administration; 2005.

32. Schechter MS, Margolis P. Improving subspecialty healthcare: Lessons from cystic fibrosis. J Pediatr. 2005;147(3): 295-301. PMID:16182664 http://dx.doi.org/10.1016/j.jpeds.2005.03.044

33. Patient Aligned Care Team (PACT) [Internet]. Washington (DC): Department of Veterans Affairs [updated 2011 Oct 19; cited 2011 Sep 13]. Available from: http://www.va.gov/ PRIMARYCARE/PACT/index.asp

34. Smith BM, Evans CT, Ullrich P, Burns S, Guihan M, Miskevics S, LaVela SL, Rajan S, Weaver FM. Using VA data for research in persons with spinal cord injuries and disorders: Lessons from SCI QUERI. J Rehabil Res Dev. 2010;47(8):679-88. PMID:21110243 http://dx.doi.org/10.1682/JRRD.2009.08.0117

35. Yano EM, Bastian LA, Frayne SM, Howell AL, Lipson LR, McGlynn G, Schnurr PP, Seaver MR, Spungen AM, Fihn SD. Toward a VA Women's Health Research Agenda: Setting evidence-based priorities to improve the health and health care of women veterans. J Gen Intern Med. 2006;21(S3 Suppl 3):S93-101. PMID:16637953 http://dx.doi.org/10.1111/j.1525-1497.2006.00381.x

Submitted for publication November 17, 2010. Accepted in revised form September 13, 2011.

This article and any supplementary material should be cited as follows:

Curtin CM, Suarez PA, Di Ponio LA, Frayne SM. Who are the women and men in Veterans Health Administration's current spinal cord injury population? J Rehabil Res Dev. 2012;49(3):351-60. http://dx.doi.org/10.1682/JRRD.2010.11.0220

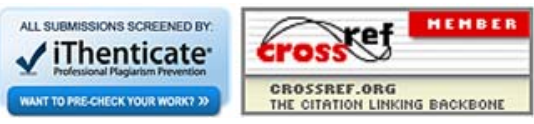

